Kidney

Blood Pressure

Research

\title{
Mechanisms of Progression in Renal Disease
}

Guest Editor

Jürgen Floege, Hannover

44 figures, 10 tables, 1999

KARGER 
S. Karger

Medical and Scientific Publishers Basel $\cdot$ Freiburg $\cdot$ Paris $\cdot$ London New York $\cdot$ New Delhi $\cdot$ Bangkok Singapore $\cdot$ Tokyo $\cdot$ Sydney
Drug Dosage

The authors and the publisher have exerted every effort to ensure that drug selection and dosage set forth in this text are in accord with current recommendations and practice at the time of publication. However, in view of ongoing research, changes in government regulations, and the constant flow of inform tion relating to drug therapy and drug reactions, the reader is urged to check the package insert for each drug for any change in indications and dosage and for added warnings and precautions. This is particularly important when the recommended agent is a new and/or infrequently employed drug.
All rights reserved.

No part of this publication may be translated into othe languages, reproduced or utilized in any form or by any means, electronic or mechanical, including photocopying, recording, microcopying, or by any information storage and retrieva system, without permission in writing from the publisher or, in the case of photocopying, direct payment of a specified fee to the Copyright Clearance Center (see 'General Information')

(c) Copyright 1999 by S. Karger AG,

P.O. Box, CH-4009 Basel (Switzerland)

Printed in Switzerland on acid-free paper by

Reinhardt Druck, Basel

ISBN 3-8055-6876-2

\section{KARGER}

Fax+4161306 1234

E-Mail karger@karger.ch

www.karger.com 


\section{Contents}

5 Role of Mesangial Cell Damage in Progressive Renal Disease Shimizu, F.; Kawachi, H.; Orikasa, M. (Niigata)

13 Role of Glomerular Endothelial Damage in Progressive Renal Disease Yamanaka, N.; Shimizu, A. (Tokyo)

21 Macrophage Activation and Programming and Its Role for Macrophage Function in Glomerular Inflammation

Erwig, L.-P.; Rees, A.J. (Aberdeen)

26 How Does Podocyte Damage Result in Tubular Damage?

Kriz, W.; Elger, M.; Hosser, H.; Hähnel, B. (Heidelberg); Provoost, A. (Rotterdam); Kränzlin, B.; Gretz, N. (Mannheim)

37 Proteinuria as a Mediator of Tubulointerstitial Injury Abbate, M.; Remuzzi, G. (Bergamo)

47 Chronic Interstitial Damage in Proteinuria: Does Complement Mediate Tubulointerstitial Injury? Sheerin, N.S.; Sacks, St.H. (London)

53 Role of Tubular Cells in Progressive Renal Disease van Kooten, C.; Langers, A.M.J.; Bruijn, J.A.; Daha, M.R. (Leiden)

62 Vasoactive Factors and Tubulointerstitial Injury Wolf, G. (Hamburg)

71 Interstitial Pathomechanisms Underlying Progressive Tubulointerstitial Damage Strutz, F.; Müller, G.A. (Göttingen)

81 Progression of Diabetic Nephropathy. Insights from Cell Culture Studies and Animal Models Phillips, A.O. (Cardiff); Janssen, U.; Floege, J. (Hannover)

98 Author Index/Subject Index

\section{KARGER}

Fax+41613061234 E-Mail karger@karger.ch www.karger.com

\section{(C) 1999 S. Karger AG, Basel}

Access to full text and tables of contents, including tentative ones for forthcoming issues: www.karger.com/journals/kbr/kbr_bk.htm 